Vol..6, No.1, 2020

Doi: https://doi.org/10.24198/cosmogov.v6i1.26632

http://jurnal.unpad.ac.id/cosmogov/index

\title{
PUBLIC PERCEPTION REGARDING MONEY POLITICS IN GENERAL ELECTION 2019 (COMPARTIVE STUDY ON TEGAL CITY AND TEGAL REGENCY)
}

\author{
Sri Sutjiatmi ${ }^{1}$ \\ Dwian Hartomi Akta Padma Eldo ${ }^{1}$ \\ Arif Zainuddin ${ }^{1}$ \\ ${ }^{1}$ Universitas Pancasakti Tegal \\ Jalan Halmahera No. KM, Mintaragen, Tegal Timur, Tegal City, Central Java, Indonesia
}

Email: dwianhartomieldo@upstegal.ac.id

Submitted: March 13 2020, Reviewed: April 14, 2020, Accepted: May 05, 2020

\begin{abstract}
This paper is intended to look at the condition of Indonesia related to the still rampant occurrence of money politics which is a problem in the community when the 2019 elections simultaneously. This research takes a case study between Tegal City and Tegal Regency. The interesting thing in this study is to see how the community's assessment of the Tegal city and Tegal Regency groups regarding money politics in the 2019 elections simultaneously. The method used is a mixed method (between Mixed Methods) between quantitative and qualitative, by calculating the Solvin formula by deepening the analysis by interviewing the speakers directly. The results of the study showed that the people of Tegal City had a relatively high attitude of not paying attention to the Politics of Money in the General Election relating to the political money of the General Elections in 2019 at the same time. Unlike the people of Tegal Regency who consider money politics as a culture that is difficult to remove. Also interesting is the beginner voter group Tegal Regency has a fairly high knowledge about money politics that can damage the democratic system compared to the Beginner voters in Tegal City.
\end{abstract}

Keywords: Comparison of Perception, Money Politics, Elections

\begin{abstract}
ABSTRAK
Tulisan ini bertujuan untuk melihat kondisi Indonesia terkait masih maraknya terjadi politik uang yang menjadi masalah ditengah masyarakat saat pemilu serentak 2019. Penelitian ini mengambil studi kasus antara Kota Tegal dan Kabupaten Tegal. Hal menarik dalam penelitian ini adalah melihat bagaimana perbandingan persepsi masyarakat berdasarkan kelompok usia antara masyarakat kota Tegal dan Kabupaten Tegal perihal politik uang pada pemilu serentak 2019 yang lalu. Metode yang digunakan adalah metode campuran (Mixed Method) antara kuantitatif dan kualitatif, dengan pendekatan rumus solvin dengan pendalaman analisis dengan wawancara dengan narasumber secara langsung. Hasil penelitian menunjukkan bahwa masyarakat Kota Tegal memiliki sikap ketidak pedulian yang cukup tinggi mengenai Politik Uang dalam Pemilu meskipun mereka mengetahui terkait beredarnya politik uang saat Pemilu serentak 2019 yang lalu. Berbeda dengan masyarakat Kabupaten Tegal yang mereka menganggap politik uang sebagai Budaya yang ada yang sulit dihilangkan. Selain itu yang menarik adalah kelompok pemilih pemula Kabupaten Tegal memiliki pengetahuan yang cukup tinggi mengenai bahaya politik uang yang dapat merusak system demokrasi dibandingkan pemilih Pemula yang ada di Kota Tegal.
\end{abstract}

Kata Kunci: Perbandingan Persepsi, Politik Uang, Pemilu 
Vol..6, No.1, 2020

Doi: https://doi.org/10.24198/cosmogov.v6i1.26632 http://jurnal.unpad.ac.id/cosmogov/index

\section{BACKGROUND}

Elections (Elections) become one form of running a good democracy in a country that adheres to the democratic system itself. Democracy is a concept or instrument of power whose mechanism of state management is based on the will of the majority of people's voice (Nurtjahyo, 2006).

The election is one of the pillars of democracy which is very important as a form of people's sovereignty to produce a democratic government. It also gets strong legitimacy and trust because it is directly elected by the people. The election can be considered as one of the foundations of democracy because the people are actively and directly involved in determining the direction of political policy in a country for the next period of leadership. Elections were going to form Government which represents the joint of all national elements to form and continue the conception of statehood (Arrsa, 2014).

Democracy is generally acceptable than the authoritarian system. A system and application of elections run based on fairness and justice. To ensure a smooth electoral process, the main thing to consider is the regulation on the election.

The life of democracy will never be separated from political parties as a container of aspirations and a place of struggle for the best cadres of the nation who want an even better life. However, the worrying fact is that most political parties have a problem with money politics during the Election and Regional Election (Kumorotomo, 2009). This is no longer a general secret where money politics and political parties have a fairly close relationship.

Lack of understanding of the foundation and substance of democracy results in the majority of Indonesians think democracy as merely a ritual (elections, voting, voting, freedom of opinion, etc.) while its relevance to improving the quality of public policy tends to be ignored (Zen, 2015).

Weak public trust in their representatives as members of the council is one of the factors that inhibit public participation in the public policy process. Many people feel that their representatives only make many promises and does not come true.

The problem of money politics is familiar in today's society, which is carried out by those who want to win the election. The various efforts also often heard coming from candidates to win the fight. Everything is considered a phenomenon that is common and develops in society (Qodir, 2014).

It was a pity when you heard about issues of election violations that often occurred. Most people have been satisfied with what was obtained for a moment by these elements. It has become a common thing in every election to take place there will be money politics problems that arise.

One of the logical reasons behind the practice of money politics which is still tightly linked to the pragmatic type of floating voters (Sihidi et al., 2019). Voters who are floating become the main targets of money politics because these conditions are always used by individuals to be able to lead voters to vote following the wishes of unscrupulous money politics spreaders. A 
Vol..6, No.1, 2020

Doi: https://doi.org/10.24198/cosmogov.v6i1.26632

http://jurnal.unpad.ac.id/cosmogov/index

good political education is needed from the community in this fight which always happens in the contestation of elections and local elections

The direct election system carried out by the State of Indonesia currently has its own story, especially after the reformation as it is today. Starting with the Elections of 2004, 2009 and 2014, they have their own historical record considering that the election is democratic in the history of the Indonesian Nation because the people can directly elect their representatives who will sit in the parliament following the president and vice president.

Elections in 2019 known as the most complicated elections in the world because the several types of the election must be carried out on same time, People have to elect members of the House of Representatives (DPR), Regional Representative Council (DPD), Provincial DPRD, and Regency / City DPRD, then the president and vice president (Dewi, 2015).

All election which happened after the reformation has its own story especially violations, one of the violations is money politics. Money politics defined as a form of giving or promising to bribe a person or group so the person does not run his right to vote in elections and money politics form as money or thing.

The current condition, money politics is one of the poisons of democracy that must be erased by everyone. Indeed the poison of democracy appears in various forms and always grow during election. They are; (1) Money politics, (2) Black Campaigns, (3) Campaigns containing SARA, (4) Hoax news, (5) Abstentions.

Money politics is one of the serious problems that must be faced every election in Indonesia. For more details, some cases and reports on money politics that occurred in the post-reform election can be seen in Table 1 below.

Table 1. Money Politics Report after Reformation Era

\begin{tabular}{|c|c|c|c|c|}
\hline $\mathrm{NO}$ & Years & Cases & Place & Result \\
\hline 1 & 2004 & $\begin{array}{l}114 \text { cases founded } \\
\text { regarding on Hous of } \\
\text { Representative. (Data } \\
\text { from ICW). }\end{array}$ & $\begin{array}{c}\text { Spreads at some } \\
\text { Indonesia Regional }\end{array}$ & $\begin{array}{l}\text { Giving in the form like } \\
\text { money, thing, and } \\
\text { something like tickets }\end{array}$ \\
\hline 2 & 2009 & $\begin{array}{l}150 \text { money politics cases } \\
\text { at } 4 \text { big city. (Data from } \\
\text { ICW). }\end{array}$ & $\begin{array}{l}\text { Jakarta, Semarang, } \\
\text { Surabaya, dan } \\
\text { Makasar }\end{array}$ & $\begin{array}{c}\text { Giving like money, and } \\
\text { things. }\end{array}$ \\
\hline 3 & 2014 & $\begin{array}{l}313 \text { Money politics case } \\
\text { founded at } 2014 \text { (Data } \\
\text { form ICW). }\end{array}$ & $\begin{array}{l}\text { Spreads on } 5 \\
\text { Provinces in } \\
\text { Indonesia }\end{array}$ & $\begin{array}{l}\text { Giving like money, } \\
\text { thing, services, and the } \\
\text { nature resources for } \\
\text { country. }\end{array}$ \\
\hline 4 & 2019 & $\begin{array}{l}4 \text { people which taken on } \\
\text { OTT in Pekanbaru } \\
\text { City(Taken on } \\
\text { kompas.com) }\end{array}$ & Pekanbaru & $\begin{array}{l}\text { Rp. } 506.400 .000 \\
\text { spreaded. }\end{array}$ \\
\hline
\end{tabular}


Vol..6, No.1, 2020

Doi: https://doi.org/10.24198/cosmogov.v6i1.26632 http://jurnal.unpad.ac.id/cosmogov/index

In the table 1, It can be seen that money politics is a serious problem in the grand celebration of the Indonesian Democratic party. This condition is also supported by the behaviour of Indonesian people who are still primitive or lack of public education about money politics. Then in facts, there are still those who offer their votes to be bought.

These conditions will damage to image of demoralization itself in every country. For any reasons, it becomes interesting to study the public's perception regarding money politics which always occurs during elections. Then if the practice of money politics is not immediately resolved and eradicated, there will be a problem of accountability and democratic representation again. Money politics in Indonesia broke the accountability of the policymaking process, both in the executive and legislative branches (Muhtadi, 2013).

The practice of money politics in elections is usually run by expert agents (candidates for village head and success teams) and lay agents, or voters in addition to the success team. The agents use campaign activities to practice money politics. While the manifestation of money politics is interaction between expert agents and lay agents like money (cash), things and the delivery of political promises (Amanu, 2015).

Money politics is transactional for candidates and voters to give benefit to each other in elections. These mutually beneficial conditions actually broke democratic values in the election because money can be injuring an honesty, sportive and make the election is not fair for other candidates (Lukmajati, 2016).

Democracy becomes a party for everyone that exists, both at the rural community and the urban community. Everyone has a right to celebrate the democracy party with or without money politics. Nevertheless, in a sociological approach there is clear difference between the urban community and the village community in any approach to taking action, including in dealing with money politics.

Most of the rural community have a job closely related to earth, and they are still very obedient to the beliefs they hold by prioritizing mutual cooperation (Jamaludin, 2017).

Inversely with urban communities such as those (Jamaludin, 2017) say that urban society members are separated, not knowing each other, and are bound by family and their relationships are straightforward. So there are differences in urban and rural communities in approaching things in the social life of society.

This matter will also affect to the community to face money politics which also be problematic in urban and rural communities. Therefore, this study will look the comparation Tegal City people's perceptions and the people of Tegal Regency toward money politics issues based on age

\section{METHOD}

This research use Mixed Methods, that means the research step by combining two existing research forms, including qualitative and quantitative. According to 
Vol..6, No.1, 2020

Doi: https://doi.org/10.24198/cosmogov.v6i1.26632

http://jurnal.unpad.ac.id/cosmogov/index

(Creswell, 2010: 5) mixed research is a research approach that combines qualitative research with quantitative research.

For more details (Creswell, 2010: 6) explains that there are at least three basic reasons why researchers use mixed research. First, it use to test the results of research at an early stage when going forward a research stage.

Second, explain in more detail the results of the study and describe it in its entirety. Third, it gives a full understanding of qualitative and quantitative research which stands alone. It means that will be mutually supportive between qualitative and quantitative data to get a better understanding, than choosing one of these methods.

Therefore the researcher considers mixed methods is the selection of methods that are quite appropriate in approaching respondents who are heterogeneous and require deep analysis as a comparison

The type of mixed methods strategy used in this study is a sequential/gradual mixed method strategy. This strategy can be done with interviews in advance to obtain qualitative data, followed by quantitative data, in this case, using a questionnaire (Creswell, 2010: 316-318).

The population in this paper are all the people of Tegal City and Tegal Regency who have entered the permanent voter list in 2019 simultaneous elections and use a sample of 200 respondents who were chosen by the Slovin technical approach according to (Sugiyono, 2011). Quantitative data analysis techniques using the application of SPSS in crosstab data processing/cross-tabulation that will connect between several variables.

\section{RESULT AND DISCUSSION}

Money politics is not a new thing in national elections or regional elections. Money politics becomes a serious problem that must be handled by everyone.

\section{Money Politics Information}

They need high level of awareness in terms of fighting money politics. The current condition is many people perceive that money politics is a common thing happens in the community, both at the urban and rural level. In this case especially the people of Tegal City and Tegal Regency.

Table 2. Money Politics Information in Tegal Regency

\begin{tabular}{cccc}
\hline age & Very Knew & Knew & Not Knew \\
\hline $17-30$ & 0 & 22 & 2 \\
$31-45$ & 2 & 18 & 6 \\
$46-60$ & 2 & 12 & 12 \\
& & & 16 \\
60 -above & 2 & 6 & 36 \\
Total & 6 & 58 &
\end{tabular}


Vol..6, No.1, 2020

Doi: https://doi.org/10.24198/cosmogov.v6i1.26632

http://jurnal.unpad.ac.id/cosmogov/index

Can be seen in table 2 regarding the extent to which information is obtained by the people of Kab. Tegal concerning money politics during the last 2019 election that from any age group. They knew about the existence of money politics in circulation by $58 \%$ of Tegal regency respondents. The answer is very known as much as $6 \%$. This shows that the Regency community knows that there is money politics during the 2019 simultaneous elections.

It was not different with the people of Tegal City, They knew the spread of money politics in Tegal City itself. It can be seen in table 3 below

Tabel 3. Money Politics Information by Tegal City

\begin{tabular}{ccccc}
\hline Age & Very Knew & Knew & Not Knew & Very not knew \\
\hline $17-30$ & 6 & 10 & 10 & 2 \\
$31-45$ & 2 & 18 & 8 & 0 \\
$46-60$ & 0 & 16 & 8 & 2 \\
& & 8 & 10 & 0 \\
60 - above & 0 & 52 & 36 & 4 \\
Total & 8 & Data managed by SPSS, 2020
\end{tabular}

It can be seen in table 3 that the people of Tegal City and Tegal Regency had not difference, regarding the information obtained related to the circulation of money politics during the 2019 election yesterday. It can be seen that the respondents who answered were very knowledgeable and knew about the existence of money politics as much as $60 \%$, which means that more than half of respondents who knew about money politics during the simultaneous elections in 2019. Only $40 \%$ of people who answer don't know and really don't know.

There is an interesting note that can be seen, that it turns out for the millennial group or the age range of 17-30 years who get a lot of information about money politics in circulation. It means that young people are quite active in receiving information at the time when elections run simultaneously.

\section{Public Respons Toward Money Politics} Issue

Next, how people based on age groups respond to the many issues of money politics during the 2019 simultaneous elections. For more details can be seen in table 4 below:

Table 4. Public Respons of Tegal City Regarding Money Politic During 2019 Election

\begin{tabular}{ccccc}
\hline Age (year) & $\begin{array}{c}\text { let money } \\
\text { politics work }\end{array}$ & Enjoy & Become a culture & Reported \\
\hline $17-30$ & 8 & 4 & 4 & 12 \\
$31-45$ & 6 & 2 & 14 & 6 \\
$46-60$ & 14 & 4 & 2 & 6 \\
& 8 & 4 & 6 & 0 \\
\hline
\end{tabular}


Vol..6, No.1, 2020

Doi: https://doi.org/10.24198/cosmogov.v6i1.26632

http://jurnal.unpad.ac.id/cosmogov/index

\begin{tabular}{cccc}
\hline $\begin{array}{c}\text { 60- above } \\
\text { Total }\end{array}$ & 36 & 14 & 26 \\
\hline \multicolumn{4}{c}{ Data managed by SPSS, 2020 }
\end{tabular}

Table 4 above is the result of the responses from the people of Tegal City about information related to money politic. It can be seen that in general, the people of Tegal city are very resisted with the existing money politics, they answered that let money politics occurs with a percentage of $36 \%$. It means that there is a straight line between the lifestyle of Tegal city people and they do not care about what is happening around.

Based on table 4 it can be concluded that the people of Tegal were more likely to let money politic occurs. Even so, the millennial group aged 17-30 years also includes groups who enjoy money politics that circulated during the elections at the same time.

In Tegal, it turns out that political education and political awareness of millennial voters is quite high by showing that even though many know about money politics and knowing what needs to be done when knowing about money politics. Reporting to the authorities is the attitude taken by millennial voters when they learn that there is still money politics spread among the people.

As a comparison in Tegal Regency regarding the attitude shown when knowing money politics can be seen in Table 5 below.

Table 5. Public Respons of Tegal Regency Regarding Money Politics During 2019 Election

\begin{tabular}{ccccc}
\hline Age (year) & $\begin{array}{c}\text { Let money } \\
\text { politics occurs }\end{array}$ & Enjoy & $\begin{array}{c}\text { Become a } \\
\text { culture }\end{array}$ & Reported \\
\hline $17-30$ & 6 & 4 & 12 & 2 \\
$31-45$ & 10 & 0 & 12 & 4 \\
$46-60$ & 4 & 0 & 8 & 14 \\
60-above & 8 & 2 & 4 & 8 \\
Total & 28 & 6 & 36 & 28 \\
\hline \multicolumn{5}{c}{ Data managed by SPSS, 2020 }
\end{tabular}

In table 5 above, it can be seen the differences between the people of Tegal City and Tegal Regency, which in Tegal Regency tends the village lifestyle. In Tegal Regency, the public has considered money politics at the time of the election to be a common and cultural thing. It means that money politics in elections has long existed when the elections took place both at the village level and the regional level who also elected the regional head and village head.
It can be seen in the table that the people of Tegal Regency, in general, assume that money politics has become a culture with respondents answering 36\%. But there are differences in attitudes shown by millennial voters from Tegal Regency and Tegal City.

Millennial voters have low political awareness about their attitude in getting information related to money politics. Millennial voters still have very low 
Vol..6, No.1, 2020

Doi: https://doi.org/10.24198/cosmogov.v6i1.26632 http://jurnal.unpad.ac.id/cosmogov/index

awareness to report to the authorities, they also consider money politics to be a culture that exists when elections take place at any level.

Regarding on facts above, it will be sad to see that the true democracy value in the national life for political awareness is millennial voters who will replace future leadership. Millennial voters should not be pessimistic about it, because the millennial group must be able to fight all of the problems in this nation, including money politics, which are problems in democracy.

All age groups have high responsibilities regarding political education. Good political education will be able to make a meaningful contribution to the course of democracy in Indonesia.

\section{The Public Understanding to Money Politics Include on Election Violations}

The public is also demanded to be active against all forms of existing election violations. Currently, The problem is the extent to which the public can understand what is included in election violations. Table 6 will show the public's understanding of money politics included in election violations.

Table 6. Public Understanding in Tegal City Regarding Money Politics Iclude on Election Violation

\begin{tabular}{ccccc}
\hline Age (Year) & $\begin{array}{c}\text { Vey } \\
\text { understanding }\end{array}$ & Understand & $\begin{array}{c}\text { Do not } \\
\text { understanding }\end{array}$ & $\begin{array}{c}\text { They don't } \\
\text { understand at } \\
\text { all }\end{array}$ \\
\hline $17-30$ & 4 & 22 & 2 & 0 \\
$31-45$ & 2 & 18 & 8 & 0 \\
$46-60$ & 0 & 14 & 12 & 0 \\
$60-$ above & 0 & 2 & 16 & 2 \\
Total & 6 & 56 & 38 & 2 \\
\hline \multicolumn{5}{r}{ Data managed by SPSS, 2020 }
\end{tabular}

Table 6 shows how high people's understanding of money politics is in the category of election violations. Tegal City people in general from the age group show that they understand enough that money politics is one of the violations of the election. It is shown with respondents' responses as $62 \%$.

There is an interesting finding, that the people of Tegal City with their age group as millennial voters, in general, are the most understanding related to money politics which is categorized as election violations. Whereas there are quite a lot of age groups above the age of 46 who do not know that money politics is included in the category of election violations.

It shows that Tegal City People are included in the category of Millennial who previously thought that money politics was normal, knew if money politic was included in the category of election violations.

As a comparison table 7 will show the same thing about the understanding of the people of Tegal Regency who know that money politics is included in the category of election violations. 
Vol..6, No.1, 2020

Doi: https://doi.org/10.24198/cosmogov.v6i1.26632

http://jurnal.unpad.ac.id/cosmogov/index

Tabel 7. Public Understanding in Tegal Regency Regarding Money Politics Iclude on Election

\begin{tabular}{ccccc}
\hline Age (Year) & $\begin{array}{c}\text { Vey } \\
\text { understanding }\end{array}$ & Understand & $\begin{array}{c}\text { Do not } \\
\text { understanding }\end{array}$ & $\begin{array}{c}\text { They don't } \\
\text { understand at } \\
\text { all }\end{array}$ \\
\hline $17-30$ & 2 & 22 & 0 & 0 \\
$31-45$ & 6 & 20 & 0 & 0 \\
$46-60$ & 12 & 12 & 2 & 0 \\
60 - above & 4 & 6 & 10 & 4 \\
Total & 24 & 60 & 12 & 4 \\
\hline \multicolumn{5}{c}{ Data managed by SPSS, 2020 }
\end{tabular}

Society has different characteristics in understanding something. Education can influence how the understanding of something. Understanding of election violations in the community of Tegal Regency is quite high, as indicated by $84 \%$ of respondents' answers who answered with understand and very understanding that money politics is included in the category of Election Violations.

This understanding proves that although people consider money politics to be a culture in every election, they understand that money politics is included in election violations. The public's understanding is still not fully able to make an impact and fight the existing money politics in every election. The real action is needed together in fighting money politics.

That was not much different from the people of Tegal City, it turns out that the people of Tegal Regency with the millennial age group of voters who understand that money politics is included in the category of election violations. The age group that falls into the vulnerable age of 46 years do not understand that money politics is included in the category of election violations that can damage democracy.

Money politics becomes an obstacle of good democracy in country. The leaders have not the same opportunity to become a leader in their own country. It will continue and only give benefits to the owners of capital.

\section{Public Understanding Regarding a Dangerous of Money Politic for Democracy. \\ Good political education can be} seen with the level of understanding of the dangers of money politics which always occurs when the 2019 elections run simultaneously. The comparison can be seen in the people of Tegal City in table 8 below.

Table 8. Public Understanding in Tegal City Regarding a Dangerous of Money Politic for Democracy Life

\begin{tabular}{ccccc}
\hline Age (Year) & $\begin{array}{c}\text { Vey } \\
\text { understanding }\end{array}$ & Understand & $\begin{array}{c}\text { Do not } \\
\text { understanding }\end{array}$ & $\begin{array}{c}\text { They don't } \\
\text { understand at all }\end{array}$ \\
\hline $17-30$ & 0 & 24 & 4 & 0 \\
$31-45$ & 2 & 14 & 12 & 0 \\
\hline
\end{tabular}


Vol..6, No.1, 2020

Doi: https://doi.org/10.24198/cosmogov.v6i1.26632

http://jurnal.unpad.ac.id/cosmogov/index

\begin{tabular}{ccccc}
\hline $46-60$ & 0 & 12 & 14 & 0 \\
60 - above & 0 & 4 & 10 & 4 \\
Total & 2 & 54 & 40 & 4 \\
\hline
\end{tabular}

It can be seen in Table 8 about the people's understanding of the dangers of money politics in democratic life. The people of Tegal City have $56 \%$ high understanding of the dangers of money politics that circulated during the election in 2019. But there are still Tegal City people groups still do not know the impact that exists due to money politics. As many as $46 \%$ of respondents who answered they did not know about the dangers of money politics that occurred.
It proves that the people of Tegal City are still not high enough in political education, especially money politics. It become a the responsible for all people that they have to a understand a dangers of money politics, so that money politics does not become a culture anymore in every democratic party event or elections.

As a comparison, table 9 can be seen regarding Tegal Regency people's understanding of the dangers of money politics below.

Table 9. Public Understanding in Tegal Regency Regarding a Dangerous of Money Politic for

\begin{tabular}{ccccc}
\multicolumn{5}{c}{ Democracy Life } \\
\hline Age (Year) & $\begin{array}{c}\text { Vey } \\
\text { understanding }\end{array}$ & Understand & $\begin{array}{c}\text { Do not } \\
\text { understanding }\end{array}$ & $\begin{array}{c}\text { They don't } \\
\text { understand at all }\end{array}$ \\
\hline $17-30$ & 2 & 16 & 6 & 0 \\
$31-45$ & 2 & 18 & 6 & 0 \\
$46-60$ & 4 & 22 & 0 & 0 \\
& 2 & 10 & 10 & 2 \\
60 - above & 10 & 66 & 22 & 2 \\
Total & \multicolumn{4}{c}{ Data managed by SPSS, 2020 }
\end{tabular}

Table 9 shows that the high level of understanding of the people of Tegal Regency to the dangers of money politics that can damage the democratic system for this country. The people of Tegal Regency responded with answers that were very knowledgeable and knew about the dangers of money politics by $76 \%$ and only $24 \%$ of those who did not know about the dangers of money politics that clashed during the elections.

This shows a quite high difference between the people of Tegal City and the people of Tegal Regency where the people of Tegal Regency have a high understanding, especially regarding the dangers of money politics that will have a significant impact on democratic life.

This relates to the political education of the community which still needs to be improved for the people of Tegal City. It proves that there is a correlation between people who do not respond to the spread of money politics or leave it and low level of political education related to the dangers of money politics. 
Vol..6, No.1, 2020

Doi: https://doi.org/10.24198/cosmogov.v6i1.26632 http://jurnal.unpad.ac.id/cosmogov/index

Unlike the people of Tegal City, the people of Tegal Regency who considered that money politics at the time of the election had become a culture and a common thing turned out to have an understanding of the dangers of money politics itself in democratic life.

\section{CONCLUSION}

Democratic life demand elections in a country with the aim of good leadership circulation so that will be easier to achieve the ideals in the welfare of society.

A good election is an election that runs without any violations occurs which in fact will damage the democratic order itself. Money politics is one of the problems in every election. Money politics cannot be resisted if you just hand over these responsibilities to the authorities. Because it takes a joint effort to fight and eradicate money politics.

Public perceptions must be corrected again regarding the money politics that existed during the election. Therefore the conclusions that can be drawn regarding the comparison of the perceptions of Tegal City People and Tegal Regency People as follows:

First, the people of Tegal City don't concerned with money politics. They are more likely to let it go despite knowing the existence of money politics in the 2019 elections simultaneously. Second, the people of Tegal Regency have considered money politics as a culture that cannot be eliminated. Third, the beginner voter group of the Tegal Regency People has a high political awareness compared to the novice voter of the Tegal City people regarding the dangers of money politics that fall into the category of election violations.

\section{REFERENCE}

Amanu, M. (2015). Politik Uang dalam Pemilihan Kepala Desa ( Studi Kasus di Desa Jatirejo Kecamatan Banyakan Kabupaten Kediri) Mohamad Amanu 105120101111019.

Arrsa, R. C. (2014). Pemilu Serentak dan Masa Depan Konsolidasi Demokrasi. (169).

Creswell, J. W. (2010). Research design: pendekatan kualitatif, kuantitatif, dan mixed. Yogyakarta: Pustaka Pelajar.

Dewi, S. (2015). SIKAP DAN PEMAKNAAN PEREMPUAN MARGINAL TERHADAP POLITIK UANG: Studi Kasus Pemilu Tahun 2014 di Kabupaten Kudus. Addin, 9(1), 205-228.

Jamaludin, A. N. (2017). Sosiologi perkotaan (Memahami masyarakat Kota dan Problematikanya) (ke-2). Bandung: CV Pustaka Setia.

Kumorotomo, W. (2009). Intervensi Parpol, Politik Uang dan Korupsi: Tantangan kebijakan Publik Setelah Pilkada Berlangsung. Konferensi Administrasi Negara, (32), 1-18.

Lukmajati, D. (2016). Praktek Politik Uang dalam Pemilu Legislatif 2014 (Studi Kasus di Kabupaten Blora). 7(1), 1-24.

Muhtadi, B. (2013). Politik Uang Dan Dinamika Elektoral Di Indonesia: Sebuah Kajian Awal Interaksi Antara Party-Id Dan Patron-Klien. Jurnal Penelitian Politik, 10(1), 369. Retrieved from http://ejournal.politik.lipi.go.id/inde x.php/jpp/article/view/217

Nurtjahyo, H. (2006). Filsafat Demokrasi. Jakarta: Bumi Aksara.

Qodir, Z. (2014). Politik Uang Dalam Pemilu-Pemilukada 2014: Modus dan Resolusinya. Jurnal Administrasi Pemerintahan Daerah, 8(2), 39-54. 
Vol..6, No.1, 2020

Doi: https://doi.org/10.24198/cosmogov.v6i1.26632

http://jurnal.unpad.ac.id/cosmogov/index

Sihidi, I. T., Khanifah, L. N., Romadhan, Sugiyono. (2011). Metode Penelitian A. A., Pemerintahan, D. I., Malang, U. M., \& Malang, K. (2019). RELASI POLITIK UANG DAN PARTY-ID DI INDONESIA. (2), 204-220.

Kuantitatif, Kualitatif dan $R \& D$. Bandung: Alfabeta.

Zen, H. (2015). Politik Uang Dalam Pandangan Hukum Positif Dan Syariah. Al-'Adalah, 12(3), 525540. 